\title{
Justicia popular: el castigo de la comunidad en España, 1895-1923*
}

\author{
Óscar Bascuñán Añover ${ }^{1}$ \\ Universidad Complutense de Madrid \\ oscarbas@ucm.es
}

RESUMEN: El artículo analiza las numerosas tentativas de linchamiento popular que tuvieron lugar en la España de la Restauración. El principal objetivo reside en esclarecer las causas, lógicas y procesos históricos de este fenómeno de violencia colectiva. Para ello, se examinan los comportamientos sociales que suscitaron este tipo de reacción popular, las prácticas sociales, significados culturales y usos politicos que se manifestaban en estas expresiones de violencia y su relación con los procesos y estructuras politicas del Estado. Consideradas en el pasado como estallidos de ira y venganza propios de una sociedad atrasada, estas formas de violencia revelan el propósito de castigar una infracción que rebasaba los límites de lo tolerado por la comunidad, formas propias de entender la justicia y una preocupación compartida por mantener normas de conducta que preservasen ciertos modos de convivencia e integridad de la población. A su vez, estas acciones descubren la existencia de otras prácticas de castigo en la sociedad muy diferentes a los procedimientos liberales, que pudieron persistir o alimentarse en un contexto de desconfianza y descrédito de los representantes públicos e instituciones del Estado. La investigación se funda en la exploración de la prensa nacional y provincial, las fuentes gubernamentales, judiciales y bibliográficas.

* Este trabajo ha sido posible gracias al apoyo de dos proyectos de investigación financiados por el Ministerio de Economía y Competitividad, ref. HAR2015-64076-P y ref. HAR201565115-P.

Para la realización de esta investigación se han consultado los fondos de la Biblioteca Virtual de Prensa Histórica del Ministerio de Cultura y Deporte, del Archivo Histórico Nacional (Madrid), del Archivo de la Dirección General de la Guardia Civil (Madrid) y del Archivo del Ministerio de Justicia (Madrid).

1 ORCID iD: https://orcid.org/0000-0002-5463-8697.

Copyright: (C) 2019 CSIC. Este es un artículo de acceso abierto distribuido bajo los términos de una licencia de uso y distribución Creative Commons Reconocimiento 4.0 Internacional (CC-BY 4.0) 


\section{PAlABRAS ClAVE: justicia popular; comunidad; linchamiento; violen- cia; castigo; Restauración.}

Popular justice: punishment meted out by the community in Spain, 1895-1923

ABSTRACT: The article analyses the numerous attempts at popular lynching that took place in Restoration Spain. The main objective is to clarify the causes, rationale and historical processes behind this phenomenon of collective violence. To do so, we study the social behaviour that aroused this type of popular reaction, the social practices, cultural meanings and political uses that were manifested in these expressions of violence and their relationship with the political structures and processes of the State. Once considered outbursts of anger and revenge typical of a backward society, these forms of violence reveal the intent to punish an infraction that exceeded the limits of what is tolerated by the community, its own ways of understanding justice and a shared concern to maintain rules of conduct that preserve certain types of coexistence and integrity among the population. These actions in turn uncover other punishment practices used in society that are very different from the liberal procedures that might persist within or be fed by a context of distrust and discredit of public representatives and State institutions. The investigation is based on an exploration of the national and provincial press, as well as government, judicial and bibliographical sources.

KEY WORDS: popular justice; community; lynching; violence; punishment; Spain.

CÓMO CITAR ESTE ARTÍCULO/CITATION: Bascuñán Añover, Óscar, «Justicia popular: el castigo de la comunidad en España, 1895-1923», Hispania, 79/263 (Madrid, 2019): 699-725. https://doi.org/10.3989/hispania.2019.017.

La opinión popular quería suponer que Garrota era un criminal..., todo el mundo creía culpable al tío Garrota, y algunos llegaban a decir que, aunque no lo fuera, había que castigarlo, porque era un desalmado capaz de cualquier fechoría (...). El juez, después de repetidos interrogatorios, comprendió la inocencia del prendero y lo dejó en libertad. El pueblo se consideró defraudado. Por indicios, por instinto, la gente adquirió la convicción de que el tío Garrota, aunque capaz de matar a su mujer, no la había matado; pero no quiso reconocer la probidad de Andrés [médico] y del juez (...). Y no había manera de convencer a la mayoría de otra $\cos ^{2}$.

\section{INTRODUCCIÓN}

Estas líneas de Pío Baroja pertenecen a su novela El árbol de la ciencia, publicada por primera vez en 1911. La obra está inspirada parcialmente en la propia

2 BAROJA, 1996: 235-237.

Hispania, 2019, vol. LXXIX, nº 263, septiembre-diciembre, págs. 699-725, ISSN: 0018-2141, e-ISSN: 1988-8368 https://doi.org/10.3989/hispania.2019.017 
biografía del autor y pronto se convirtió en una de las más representativas del grupo de escritores que formaron parte de la denominada Generación del 98. En el pasaje citado se daba cuenta de un supuesto crimen cometido en una pequeña villa del interior peninsular. La población de esta villa creía que uno de sus vecinos había matado a su mujer y deseaba que fuese castigado. Existía un obstinado recelo popular a admitir las pruebas exculpatorias a favor del sospechoso presentadas por el médico y el juez. El pueblo desconfiaba de las intenciones y averiguaciones de estos dos, uno de ellos - además - foráneo, que hacían valer su razonamiento y autoridad como representantes de la ley y el Estado. Este episodio narrado por el autor de la novela pretendía así demostrar la situación de ignorancia, desidia y resignación en la que vivía el campesinado español a principios del siglo XX, más guiado por instintos, terquedades, odios locales y deseos de venganza que por los avances racionales del conocimiento médico y los procedimientos liberales de administrar justicia.

La magistral novela estaba bien documentada. En las primeras décadas del siglo XX y, posiblemente, desde mucho tiempo atrás, numerosos núcleos de población fueron el escenario de tentativas de linchamiento sobre los sospechosos de cometer un crimen o algún otro tipo de infracción que rebasaba los límites de lo tolerado por la comunidad. Las causas, lógicas y procesos históricos de este fenómeno social generan interrogantes que merecen ser expuestos y sometidos a discusión, con el propósito de obtener algunas respuestas o avanzar en una línea de investigación poco atendida. En primer lugar, es necesario identificar los motivos por los que determinados individuos intentaron ser o fueron linchados: ¿Qué comportamientos sociales considerados inapropiados suscitaron en ocasiones este tipo de reacción popular y colectiva? En segundo lugar, podemos dirigir la atención a las lógicas que se manifestaban en estas expresiones de violencia colectiva: ¿Eran estallidos de ira propios de la mezquindad del campesinado que representaba la literatura regeneracionista o acciones repletas de prácticas sociales, formas culturales y usos políticos en las que se pueden descubrir otras maneras de entender la justicia y el castigo? Por último, se debe intentar situar estos hechos en su contexto y preguntarse por su relación con el proceso histórico: ¿Son acciones motivadas por sentimientos de venganza innata, como si se tratase de una constante antropológica, o también denotan la existencia de un proceso contencioso en el que subyace una desconfianza en la sociedad hacia las formas de ejercer el poder, administrar justicia e impartir el castigo del Estado? Para responder con mayores certezas a las cuestiones planteadas quizás sea conveniente profundizar un poco más en el conocimiento de algunos de estos episodios.

\section{LA CHISPA DE LA INDIGNACIÓN POPULAR}

Corría el año 1905 cuando un terrible suceso sacudió el trascurso habitual de la vida en el pueblo de Cifuentes, situado en el centro de la provincia de 
Guadalajara. Las heladas del invierno habían encerrado a los vecinos en sus casas, haciendo que los días pasasen más lentos y la vida social quedase en suspenso por un tiempo. Pero en el mes de febrero algunos empezaron a echar en falta la presencia de uno de los vecinos más conocidos de la población, el ermitaño. Éste había llegado a Cifuentes hacía apenas un año, con la autorización del obispo de Sigüenza para habitar, cuidar y recoger las limosnas del santuario que se encontraba a poca distancia de la población. El ermitaño pronto se ganó las simpatías de buena parte de la población, parece que debido a su labor caritativa con pobres y enfermos, el saneamiento de la pequeña iglesia, su vida sencilla y su carácter afable. La inquietud por su desaparición se hizo mayor con el paso de las semanas y todas las sospechas comenzaron a dirigirse hacia otro vecino, el anterior ermitaño, que había sido apartado de su trabajo con la 1legada del nuevo. Los vecinos empezaron a formar las primeras concentraciones en la calle frente a las autoridades municipales y judiciales para exigir la detención del antiguo ermitaño y la búsqueda del cuerpo del que ya sospechaban que había sido asesinado. El antiguo ermitaño y su mujer fueron detenidos provisionalmente en la cárcel de la población, pero la negativa de los detenidos a reconocer los hechos propició la formación de nuevos grupos en la calle que exigían mayores esfuerzos al juez instructor para dar con el cuerpo y amenazaban con asaltar la cárcel si los detenidos eran finalmente liberados por falta de pruebas. El temor a que estallase un choque violento con las autoridades y al linchamiento de los detenidos obligó a concentrar a un buen número de guardias civiles en la población.

Días después, el cuerpo golpeado y sin vida del ermitaño apareció en el fondo de una sima que se encontraba a poca distancia del santuario. La aparición del cadáver parece que llevó al principal sospechoso a reconocer los hechos. El crimen había quedado resuelto para la población. Además, aquellos que se habían echado a la calle estaban convencidos de que su acción colectiva era la que había permitido resolver el caso y no la de la autoridad judicial, que a ojos de la población había mostrado falta de decisión y diligencia. En los meses siguientes, la lentitud en la instrucción del sumario y la impaciencia porque llegase una sentencia condenatoria convirtió al juez instructor en el centro de todas las críticas populares, expresadas también a modo de coplas satíricas. En junio, sin embargo, las críticas tomaron forma de motín. Unas seiscientas personas, en su mayoría mujeres, se concentraron en la plaza pública, rodearon la casa del juez instructor y pronunciaron «frases poco cultas» contra los agentes, los representantes de la administración de justicia y los reos, «que, hallándose en la prisión, no se ven libres de toda clase de improperios». La visita de un abogado a la cárcel para preparar la defensa del acusado había exasperado los ánimos populares. El rumor que se había extendido entre las gentes puede que fuese infundado, pero la facilidad con la que fue creído revela las ansiedades y tensiones sociales que inquietaban a la comunidad. La población temía 
que el detenido se librase de la condena que merecía. La prensa provincial, en cambio, veía en esta protesta una clara muestra de la falta de entendimiento del campesinado: «Que siendo sus moradores poco conocedores del derecho, la presencia de un letrado defensor lo traducen en que puede ser causa de que se extravíe la acción de la justicia, por no tener presente que hay un código que fija los delitos y las penas y tribunales que lo aplican en su justa proporción, sin que puedan ser seducidos ni por elocuentes párrafos de una defensa, ni mucho menos por otras cualesquiera causas». Poco tiempo después, el juez instructor tendría que ser trasladado a otra población para poder seguir ejerciendo su labor ${ }^{3}$.

Los hechos de Cifuentes podían ser excepcionales en la vida de un pueblo, pero si se amplía el espacio de estudio se puede comprobar cómo acciones muy similares a las narradas se repetían por la geografía española. En la población de Torralba de Calatrava, perteneciente a la provincia de Ciudad Real, una multitud intentó linchar a un hombre que había matado a otro por una discusión en el trabajo. Los dos trabajaban en el campo para un rico propietario de la población y ya habían tenido riñas anteriormente por deudas y rivalidades que buscaban ganarse el favor del «amo». La última pelea surgió cuando uno de ellos recriminó al otro lo mal que labraba la tierra. Los dos empuñaron sus navajas y uno se dejó allí la vida. La trágica noticia dejó helada a la población, que no terminaba de creerse lo ocurrido. El tradicional silencio de la tarde quedó roto por el llanto seco de los familiares de la víctima. La «gran indignación» no tardó en recorrer las calles del pueblo y en dar forma a los primeros grupos. Al anochecer, una gran multitud se concentraba frente a la cárcel «con intenciones nada tranquilizadoras» para el detenido. La Guardia Civil tuvo que emplearse a fondo para custodiar al preso e impedir su linchamiento, algo que solo evitaron al trasladar al detenido a la cárcel del partido judicial. Tres meses después, a poca distancia de allí, en La Solana, otra multitud imitaba el mismo comportamiento. Aquí, un vecino de la población fue asesinado de un tiro por la espalda. El autor del disparo era un hombre de una población cercana al que la víctima le debía tres pesetas. Los primeros intentos de «linchar al matador» fueron impedidos por la acción de la Guardia Civil, pero al día siguiente el motín cobró «extraordinaria gravedad». Los amotinados cortaron los hilos del telégrafo para evitar que siguiesen llegando refuerzos de la Guardia Civil y todo un gentío de «hombres, mujeres y chiquillos» se situaba frente a la cárcel con la intención de entrar «a viva fuerza». Consiguieron asaltar la cárcel a media noche, aunque para entonces el detenido había sido sacado por una

3 «El famoso sumario del ermitaño», La Crónica (Guadalajara), 1.444, 10-6-1905, y la cita textual en «La causa por muerte del ermitaño», La Crónica, 1.445, 17-6-1905. 
puerta trasera del edificio y trasladado por las fuerzas del orden a otra población ${ }^{4}$.

En algunas ocasiones, sin embargo, los agentes de la guardia civil no consiguieron contener a tiempo la indignación colectiva y evitar el linchamiento. Sucedió, por ejemplo, en 1902 en el municipio de Bergondo, de la provincia de La Coruña, donde la muerte de un joven en una pelea ocasionó el inmediato linchamiento de su supuesto agresor. Los linchadores lo molieron «a palos» y le hicieron pasar toda la noche atado a un árbol frente al cadáver de su víctima ${ }^{5}$. Un año más tarde, en el pueblo valenciano de Picasent, la muerte de otro hombre en una pelea por «motivos electorales» acabó suscitando el linchamiento del supuesto «matador», que además fue arrastrado por varias calles ${ }^{6}$. En 1911 fueron los vecinos del pueblo de Villálvaro, en la provincia de Soria, los que dieron muerte «a palos y pedradas» a un individuo sospechoso de robar ganado en repetidas ocasiones? También el vecindario de Quintanar de la Sierra, en Burgos, quiso linchar en 1919 a un sujeto que, al parecer, había «matado de un tiro» a otro vecino. Tras varias horas sin dar con el paradero del supuesto asesino, los amotinados atraparon y lincharon a su yerno. Los esfuerzos de la Guardia Civil por evitar el linchamiento resultaron inútiles. El comandante del puesto salió del enfrentamiento con los dos brazos fracturados ${ }^{8}$.

La descripción detallada de otras acciones colectivas en las que la población pretendía castigar a un criminal podría ocupar algunas páginas más. Pero antes de continuar, conviene detenerse en aclarar la utilización del término linchamiento. Su uso ha generado encendidos debates en la historiografía anglosajona por la dificultad de encontrar una definición precisa, estable en el tiempo y adecuada a diferentes expresiones colectivas de violencia extralegal. Esto ha derivado en un empeño, no siempre bien resuelto, en distinguir los linchamientos de otros fenómenos que en inglés reciben el nombre de vigilantism, mob violence o rough justice ${ }^{9}$. No obstante, las fuentes históricas que han nutrido esta investigación y, muy especialmente, la prensa de las primeras décadas del $\mathrm{XX}$, no dudaban en utilizar recurrentemente el término linchamiento para referirse a determinados episodios de violencia multitudinaria contra uno o varios individuos, como bien se puede comprobar en las palabras entrecomilladas y algunos titulares de noticias utilizadas en estas páginas. Los testimonios de la época, por tanto, ayudan a enmarcar estas acciones como expresiones de

${ }^{4}$ Lo de Torralba de Calatrava en «En la Audiencia. Causa interesante», Diario de La Mancha (Ciudad Real), 799, 18-2-1909; y lo de La Solana en «Grave motín en La Solana», Diario de La Mancha, 654, 2-9-1908.

5 «De Betanzos», El Noroeste (La Coruña), 2.023, 10-12-1902.

6 «Colisión electoral», La Correspondencia de España (Madrid), 16.712, 9-11-1903.

7 «Varias noticias», La Correspondencia de España, 19.538, 10-8-1911.

8 «Un crimen y un linchamiento», La Correspondencia de España, 22.381, 25-5-1919.

${ }^{9}$ El debate en CARRIGAN y WEBB, 2013: XI-XIV.

Hispania, 2019, vol. LXXIX, no 263, septiembre-diciembre, págs. 699-725, ISSN: 0018-2141, e-ISSN: 1988-8368 https://doi.org/10.3989/hispania.2019.017 
justicia popular en las que un grupo perteneciente a una misma comunidad pretendía o conseguía tomarse la justicia por sus propias manos de manera violenta y, al margen del procedimiento legal, castigar físicamente a uno o varios individuos acusados de haber cometido una acción considerada ofensiva o inapropiada, que agredía la moral, las normas aceptadas o la seguridad de la propia comunidad. Un poema titulado «Linchamiento» y publicado en el periódico salmantino La Democracia, ofrece una percepción cabal de lo que los coetáneos podían entender por esta práctica. Algunas de sus estrofas decían lo siguiente:

La conciencia de Juan ruin y mezquina/al sospechar la ruina/que sobre su cabeza se cernía/acarició la idea de venganza/y en una noche oscura/y a más de oscura tenebrosa y fría/sin fe, sin esperanza/en un rapto terrible de locura/asesinó a Miguel y el asesino/se labró allí su propia sepultura.

Un honrado vecino/el crimen descubrió y el pueblo noble/tomando la justicia por su cuenta/el cuerpo del traidor colgó de un roble/iAfrenta por afrenta!

Se acabaron del pueblo las rencillas/y entre aquellas sencillas/y honradas gentes la virtud acrece. $[\ldots]^{10}$.

El desarrollo de la investigación ha permitido documentar hasta ahora 89 episodios similares a los narrados anteriormente en 34 provincias, entre 1895 y 1923. En 78 ocasiones de éstas el linchamiento se quedó en una tentativa que la Guardia Civil u otros cuerpos del orden público consiguieron contener con la intervención de su fuerza, mientras en otras once el linchamiento llegó a consumarse $^{11}$. Unos números que seguramente todavía no se pueden dar por defi-

10 El poema estaba firmado por Tomás Rodríguez, «Linchamiento», La Democracia. Diario politico, literario y de noticias (Salamanca), 200, 19-7-1892.

${ }_{11}$ No existen estadísticas oficiales que registren este tipo de acciones, a diferencia de lo que sí podemos encontrar al estudiar delitos, faltas o condenas para este período. Los números ofrecidos proceden, por tanto, de una búsqueda sistemática realizada especialmente a través de las fuentes hemerográficas de la época. Periódicos de tirada nacional como La Correspondencia de España han permitido documentar varios episodios de esta naturaleza, pero ha sido la prensa de carácter provincial la que ha aumentado los números de esta relación y ha conseguido registrar episodios hasta en 34 provincias al dedicar una mayor atención a los sucesos que tenían lugar en sus entornos más cercanos. En las páginas de este artículo se hace referencia y se indica la cita de un buen número de estas acciones. La relación de periódicos consultados en los que se han documentado episodios de este carácter es la siguiente: Correo de la Mañana, Diario de Córdoba, El Bien Público, El Cantábrico, El Castellano, El Debate, El Defensor de Córdoba, El Día de Palencia, El Día de Toledo, El Diario Palentino, El Diario de la Mancha, El Eco de Santiago, El Eco de Navarra, El Guadalete, El Heraldo Toledano, El Lábaro, El Noroeste, El Norte, El Porvenir Segoviano, El Progreso, El Pueblo Manchego, Heraldo Alavés, Heraldo de Zamora, La Atalaya, La Correspondencia de Alicante, La Correspondencia de España, La Crónica, La Crónica Meridional, La Información, La Lucha, La Prensa, La Voz de Galicia, Los Debates y Noticiero Salmantino. También se han podido 
nitivos, pero que ya indican que se trataba de un fenómeno suficientemente conocido y particular. En este cómputo no están incluidas las más estudiadas protestas por los usos y recursos de la tierra, antifiscales, contra las quintas o de subsistencias ${ }^{12}$. Los vínculos entre los linchamientos o sus tentativas y estas otras manifestaciones de protesta social son estrechos y no siempre fáciles de deslindar. Estas protestas sociales pueden ser consideradas expresiones de justicia popular que pretendían reparar lo que consideraban una injusticia económica o una exigencia estatal abusiva. Además, también implicaban a la comunidad, adoptaban una expresión violenta y tenían objetivos precisos. Sin embargo, en estas acciones colectivas los amotinados solían reparar el agravio mediante la destrucción de los edificios públicos o de la propiedad de aquellos que consideraban responsables de la situación. La agresión física contra una persona determinada no era la primera acción de la multitud ni la única, tampoco el medio normalmente empleado para reestablecer el equilibrio social en la comunidad. Las agresiones en estas protestas sociales acostumbraban a ser consecuencia de las tensiones, insultos cruzados o empellones en los que podía desembocar la contienda o por la intervención de las fuerzas del orden público ${ }^{13}$.

El fenómeno de los linchamientos no era nuevo ni propio del período de la Restauración. José María Cardesín identificó al menos 80 linchamientos mortales protagonizados por la multitud sobre personas acusadas de colaborar con los franceses entre 1808 y 1810 . El número y la gravedad de los linchamientos en contextos bélicos han encontrado una explicación común en el colapso del Estado, la debilidad de las fuerzas de orden público, el desmantelamiento del sistema judicial y las animadversiones alimentadas entre la población civil por la guerra ${ }^{14}$. No obstante, la persistencia de sus tentativas en otros contextos que aquí se estudian descubre la oportunidad de ampliar el análisis histórico y sociológico de las estructuras políticas, los procesos sociales y culturales en los que se enmarcan ${ }^{15}$. Más de la mitad de estas acciones colectivas descubiertas en nuestro período de estudio se ubican en el mundo rural, aunque los espacios

documentar algunos otros episodios a través de la consulta de la Serie A de Gobernación del Archivo Histórico Nacional, provincias de Cuenca y Guadalajara; y del Historial Provincial de las Comandancias de la Guardia Civil del Archivo de la Dirección General de la Guardia Civil. El caso de esta última fuente está igualmente citado en las páginas del presente texto.

${ }_{12}$ El significado de la violencia en la protesta social ha estado fuertemente influido por las obras pioneras de RUDÉ, 2000. THOMPSON, 2000. El listado de estudios sobre protestas sociales en España ha empezado a ser extenso. Véase BAUMEISTER, 1996. GIL ANDRÉS, 2000. LUCEA AYALA, 2005. BASCUÑÁN AÑOVER, 2008. REDONDO CARDEÑOSO, 2011.

${ }^{13}$ Los diferentes modos en los que se ha manifestado la justicia popular, tanto a través de formas violentas como no violentas, en DALE, 2016.

${ }^{14}$ CARDESÍN, 2008. RANZATO, 1997.

15 TILLY, 1992.

Hispania, 2019, vol. LXXIX, nº 263, septiembre-diciembre, págs. 699-725, ISSN: 0018-2141, e-ISSN: 1988-8368 https://doi.org/10.3989/hispania.2019.017 
populares de los núcleos urbanos no fueron ajenos ni desconocedores de estas prácticas. Como se puede observar en la tabla 1, casi el $75 \%$ de ellas son respuestas multitudinarias a crímenes de sangre, los que costaban la vida de una persona. Los crímenes que ocasionaban mayor conmoción social, los infanticidios y parricidios, solían aumentar el propósito de linchar al presunto autor. Otros crímenes de sangre contra mujeres y vecinos por discusiones en el trabajo, políticas, herencias, deudas, acusaciones de robo, celos u ofensas personales también podían quedar expuestos a un intento de castigo popular. El resto de supuestos delitos e infracciones que se detallan en la tabla 1 constituyen un conjunto de acciones que igualmente habían ocasionado heridas graves a una persona y, en menor medida, atentado contra la propiedad ${ }^{16}$.

TABLA 1. Supuestos delitos o infracciones cometidas por víctimas de tentativas de linchamiento o letales, 1895-1923

\begin{tabular}{|l|c|}
\hline \multicolumn{1}{|c|}{ Supuestos delitos o infracciones } & N. $^{\mathbf{0}}$ de tentativas de linchamiento o letales \\
\hline Crímenes de sangre & 65 \\
\hline Atropellos de coche o tranvía & 9 \\
\hline Lesiones graves & 5 \\
\hline Robo o hurto & 6 \\
\hline Incendio & 1 \\
\hline Otros & 3 \\
\hline
\end{tabular}

Fuente: elaboración propia a partir de las fuentes encontradas en la Biblioteca Virtual de Prensa Histórica del Ministerio de Cultura y Deporte, la Serie A de Gobernación del Archivo Histórico Nacional y los Historiales Provinciales de las Comandancias de la Guardia Civil del Archivo de la Dirección General de la Guardia Civil.

Muchas otras formas de quebrantar las leyes, transgredir una norma, cometer un delito o agredir a un miembro de la comunidad no generaban acciones de justicia popular. Muy al contrario, las que atentaban contra la propiedad liberal de la tierra en zonas rurales donde existían verdaderas disputas por los usos y aprovechamientos vecinales, podían contar con la complicidad de buena parte de la población. Tampoco la inmensa mayoría de los delitos contra las personas, esto es, las habituales reyertas entre dos o varios individuos, amenazas, agresiones físicas o lesiones, solían pasar a mayores, aunque generasen indignación entre los implicados y sus más allegados

${ }^{16}$ Motivaciones similares han sido señaladas en el ámbito brasileño por MARTINS, 2015. 
familiares. Otros muchos enfrentamientos y agresiones a autoridades, fuerzas del orden público, recaudadores de impuestos o ejecutores de embargos recibían el respaldo implícito y, en ocasiones, público de los vecinos. Las clases populares podían mostrar un cierto grado de tolerancia o comprensión hacia determinadas expresiones violentas, que transgredían o desafiaban los códigos penales, siempre que no sobrepasasen los límites de lo consentido por la comunidad. En este sentido, las multitudes con pretensiones de linchar a alguna persona, las que forcejeaban con los agentes de la Guardia Civil y les obligaban a pedir refuerzos, las que trataban de asaltar las cárceles y, en ocasiones, lo conseguían, no parecían estar actuando en defensa de la ley o en apoyo del sistema de justicia penal, sino al margen de éste, como reacción o acción defensiva ante lo que consideraban un acto de violencia extrema, que se había pasado de la raya o resultaba particularmente repugnante. Respondían a la brutalidad de un crimen con una acción colectiva que implicaba el brutal castigo físico del presunto criminal ${ }^{17}$.

Más complejo resulta siempre responder a por qué no todos los crímenes de sangre durante estas décadas provocaron la misma acción de la comunidad, esto es, por qué en unas ocasiones pretendieron linchar al criminal y en otras, aparentemente, contuvieron la indignación. En este sentido, las respuestas podrían encontrarse analizando en el ámbito local factores circunstanciales como el tejido de relaciones familiares, afectivas o sociales de la víctima del crimen en la población, el rechazo o antipatía que podía suscitar el presunto agresor - sobre todo si exhibía habitualmente comportamientos agresivos o pendencieros, era foráneo, rico propietario o miembro destacado de alguna familia política rival- la saña o crueldad empleada en el crimen, la existencia de conflictos sociales previos, el papel desempeñado por las élites locales en la gestión del conflicto, la presencia de estructuras estatales en la población, el prestigio de sus funcionarios o representantes, así como algunos otros posibles eventos y contingencias ${ }^{18}$. Las lógicas sociales y culturales que actuaban en este tipo de violencia colectiva también pueden ayudar a despejar algunas de las incógnitas que recaen sobre estas acciones.

\footnotetext{
${ }^{17}$ Las manifestaciones de la violencia en el ámbito rural han sido analizadas en CHAUVAUD y MAYAUD, 2005. La violencia vecinal en el campo español ha sido estudiada en GÓMEZ BRAVO, 2005. BASCUÑÁN AÑOVER, 2008. REDONDO CARDEÑOSO, 2011. CABO y VÁZQUEZ VARELA, 2015. En el campo portugués ha sido estudiada por VAQUINHAS, 1996.

${ }^{18}$ Las relaciones sociales y de poder, la propagación de rumores, el ambiente social, el estado emocional y otras circunstancias particulares del escenario local para entender las causas de la violencia colectiva fueron analizadas por CORBIN, 1995.
} 


\section{Prácticas sociales, Significados culturales y usos políticos del} CASTIGO POPULAR

Las acciones narradas más arriba ponen al descubierto usos y prácticas sociales, pasiones y valores de la cultura popular. Tal como lo representan las crónicas periodísticas, las multitudes que se formaban con ademanes de linchamiento solían tener una composición social popular, lo que aleja este tipo de acciones de las promovidas por agentes o bandas especializadas en el uso de la violencia. Hombres, mujeres y hasta niños de la población en la que se había cometido el crimen o la infracción se concentraban en los espacios públicos centrales. Atraídos por la gravedad de los hechos y en medio de un ambiente tenso, se daban la mano o se sucedían diferentes estados emocionales de furia, excitación o curiosidad. En este sentido, los linchamientos revelan la existencia de ciertos valores culturales no escritos y desafiados con la muerte de un vecino. Determinados crímenes tenían el efecto de transgredir los límites de lo tolerado por la comunidad - límites que no siempre coincidían con los que marcaba la ley-, reactivar vínculos de solidaridad en unas poblaciones que mantenían ciertos lazos sociales y culturales, reforzar la identidad de un pueblo que podía sentirse consternado o agredido y provocar una violencia a modo de castigo contra los que habían violado los límites, puesto en peligro la convivencia colectiva o el buen nombre de la comunidad ${ }^{19}$.

En las formas que adoptan estas acciones colectivas y en la fuerza dramática que exhiben se pueden identificar rasgos de una violencia más coordinada que visceral, dotada de significados culturales y simbólicos ${ }^{20}$. El grupo solía seguir un guión más o menos definido que implicaba manifestar de manera pública y abierta su indignación, desafiar el poder de las autoridades que administraban justicia o custodiaban al detenido e intentar provocar daños físicos sobre los que se consideraban autores del crimen. Así, la ofensa pretendía ser repuesta con prácticas infamantes que podían llegar a apropiarse y subvertir el procedimiento penal empleado por el Estado para exhibir su autoridad y disuadir al delincuente ${ }^{21}$. El crimen que en tantas ocasiones había sido cometido de manera personal, privada, silenciosa u oculta, solo podía ser reparado con un evento público, ruidoso, comunicativo y demostrativo. Ese derecho al castigo al que se apelaba en los linchamientos, además, pertenecía a toda la comunidad donde el delito había ocurrido y no únicamente a los familiares más cercanos.

${ }^{19}$ El concepto de comunidad como herramienta para comprender los procesos de representación e identidad colectiva en las sociedades del pasado, el fortalecimiento de lazos de cohesión, la definición de amenazas y grupos adversarios en PAN-MONTOJO y PERDERSEN, 2007.

20 TILLY, 2007: 81-102.

${ }^{21}$ FOUCAULT, 1979. SPIERENBURG, 1984. TRINIDAD, 1991. OLIVER, 2008. 
La participación de la población implicaba transformar la venganza personal en una acción de escarnio público, en la que los vecinos pretendían reparar la afrenta, recuperar la reputación colectiva, castigar directamente al presunto criminal, humillarlo y expulsarlo socialmente de la comunidad. El mensaje debía llegar a todos los miembros de la comunidad y actuar en la memoria colectiva como una advertencia sobre los riesgos de rebasar lo consentido ${ }^{22}$.

La voluntad del pueblo era la que determinaba el castigo para el presunto criminal y no la sanción impersonal de un funcionario público basado en el código penal. El autor del crimen posiblemente dejaba de ser considerado un vecino y, entonces, poco importaba que el procedimiento legal afirmase garantizar sus derechos y dignidad humana. Los linchamientos o sus tentativas, de este modo, otorgaban poder a la población y ofrecían oportunidades para hacer política, exigir demandas, construir o negociar alianzas, movilizar a la opinión pública y expresar tensiones en el seno de la comunidad. El paternalismo más habitual de las autoridades locales desplegaba todos sus recursos en ocasiones como éstas $^{23}$. En Santa Cruz de Retamar, por ejemplo, la corporación municipal se esforzaba para apuntalar su prestigio y reconocimiento social en la población. Esta población de la provincia de Toledo quedó conmocionada durante un tiempo por la comisión de un parricidio. La víctima había despertado la empatía de la población, posiblemente de manera más acentuada después de que se convirtiese en víctima de un crimen atroz. La corporación del ayuntamiento se apresuró a celebrar una sesión de plenos en la que se refería a esta víctima como «honrado vecino» del pueblo y emitía una nota pública que difundía en la prensa provincial para manifestar su repulsa por el crimen cometido. El supuesto parricida, el hijo de la víctima, tuvo que sufrir todo tipo de «denuestos e improperios» de parte de una «manifestación imponentísima» que se formó cuando lo trasladaban a la cárcel del partido. Las autoridades locales aseguraban que solo su «celo desplegado» y el de la guardia civil evitó que la multitud lo hubiera linchado «a no dudarlo» ${ }^{24}$.

Esta nueva tentativa de linchamiento representaba otra demostración de fuerza popular y de desafío a unas autoridades que habían tenido que emplearse a fondo para impedir el linchamiento. Sin embargo, en la nota pública del ayuntamiento sorprende que no hubiese palabras de censura o condena hacia la

${ }^{22}$ Las prácticas, el lenguaje y los significados compartidos de la protesta social y los rituales de castigo popular en BURKE, 1991. THOMPSON, 2000. DARNTON, 2006. Las prácticas rituales de los linchamientos han generado una renovada atención en la sociedad norteamericana, caracterizada por sus conflictos raciales, donde cobraron una mayor dimensión y fueron mucho más brutales. Véase CARRIGAN, 2006. CARRIGAN y WEBB, 2013. GARLAND, 2013: 46-51. 2013

${ }^{23}$ CRUZ ARTACHO, 2009. HERRERA, MARKOFF y VILLA, 2013. MIGUEZ y CABO,

24 «Remitido», El Castellano (Toledo), 60, 9-03-1905.

Hispania, 2019, vol. LXXIX, no 263, septiembre-diciembre, págs. 699-725, ISSN: 0018-2141, e-ISSN: 1988-8368 https://doi.org/10.3989/hispania.2019.017 
multitud. El tono de la nota desprendía comprensión con la acción colectiva, que se explicaba movida por los sentimientos instintivos de una población íntegra pero ignorante de los procedimientos de la justicia. Las élites locales posiblemente pretendían así demostrar públicamente, a través de una nota en la prensa que seguro leían autoridades provinciales y gubernamentales, su eficiencia y capacidad por haber evitado una desgracia mayor y haber reconducido el intento de linchar a un presunto parricida por las vías oficiales de la administración de justicia. De igual modo, la ocasión ofrecía la oportunidad de proteger a sus vecinos de un procesamiento por desórdenes públicos o atentado a la autoridad y ganarse el reconocimiento de la población, con la que se podía sentir más unida que nunca por la conmoción del crimen. La corporación municipal se erigía en portavoz de los sentimientos populares y expulsaba de la comunidad al presunto autor del parricidio al declararlo «mal hijo de este pueblo, que por desgracia para este honrado vecindario lo viera nacer $\rangle^{25}$.

Otra tentativa de linchamiento que devino en un uso político todavía más revelador ocurrió en Almodóvar del Campo, en la provincia de Ciudad Real. Un crimen en el seno de una familia rica y distinguida conmocionó a toda la sociedad, incluida la alta sociedad, especialmente sorprendida porque alguien de su misma educación y condición social pudiese haber cometido un acto tan cruel. La prensa provincial dedicó una mayor atención al caso por lo que denominaba «la calidad de los protagonistas». Un hombre había matado a su mujer, de 22 años, de varios disparos mientras dormía, hecho que sucedió a los pocos meses de que la pareja hubiese contraído matrimonio. La indignación popular por el crimen encontraba un agravante en la cuestionada reputación pública del presunto asesino, al que se le atribuía una «vida licenciosa con anterioridad al matrimonio», mientras que la víctima era representada por sus «virtudes sin tacha $»^{26}$. El día del sepelio - apuntaba la crónica periodística - «estaba reu-

25 «Remitido», El Castellano, 60, 9-03-1905.

${ }_{26}$ «El crimen de Almodóvar», El Pueblo Manchego (Ciudad Real), 3.192, 06-09-1921. Las informaciones de los días siguientes al crimen ahondaban en la caracterización estereotípica del criminal y la víctima con relatos como los siguientes: «Los móviles del crimen están todavía por descifrar si bien el clamor público absuelve de la más mínima culpa a la víctima, dechado de todas las virtudes y acusa implacablemente al asesino, sujeto de pésimos antecedentes, aunque muy inteligente, que ha viajado mucho por Méjico y Estados Unidos, haciendo una vida completamente de disipación. La víctima fue al matrimonio verdaderamente enamorada de su asesino y hasta la noche anterior del crimen, cuantas personas frecuentaban la casa y la misma servidumbre certifica, la luna de miel no había sufrido por parte de la difunta el eclipse más insignificante. Se trata sencillamente de un caso tan monstruoso como inexplicable». «El Sr. Solano evita el linchamiento de un asesino», El Pueblo Manchego, 3.193, 07-091921. La misma representación se repetía con otros presuntos criminales que fueron o a punto estuvieron de ser linchados, como si se tratase de un mismo recurso argumental que pretendía transmitir comprensión y empatía con la acción popular de castigo. El supuesto asesino linchado hasta la muerte en Cabuérniga (Santander) era denominado «pendenciero y ladrón» en 
nido todo el vecindario» frente a la casa de la víctima, «ardiendo en sed de venganza contra el asesino». Antes de que el coche fúnebre se pusiese en marcha con los restos mortales, la multitud se dirigió a la cárcel con el propósito de «extraer al asesino y ejecutarlo en la plaza pública». Diez parejas de la Guardia Civil tuvieron que utilizar todos sus medios persuasivos y coercitivos para contener a la multitud y evitar el «choque brutal $»^{27}$.

No obstante, el diario El Pueblo Manchego, vocero de intereses y redes clientelares en la provincia, destacaba el papel desempeñado en la disuasión del linchamiento por Ramón Solano Manso de Zúñiga, notario, alcalde de la población y diputado a Cortes. Éste — según narraba el periódico - se había asomado al balcón del ayuntamiento en el preciso momento en el que la multitud confrontaba con la Guardia Civil «exhortándole a que desistiera de la aplicación de la ley de Linch porque él se comprometía solemnemente a que el asesino fuera ajusticiado $\rangle^{28}$. El linchamiento fue evitado una vez más, ya fuese por la intervención de las fuerzas del orden, las personalidades locales o la interacción de ambas. Aun así, el periódico alababa la «viva participación» que había tomado el vecindario en estos sucesos. Ni una sola palabra amarga cuestionaba las violentas intenciones de la multitud. Los mayores elogios, eso sí, estaban dirigidos al alcalde y diputado, al que pocos días después el diario le cedía dos columnas para que explicase los hechos acaecidos en esa mañana. El artículo, escrito de su puño y letra, estaba encabezado por un título elocuente: « ¿Cuando el pueblo ruge, pidiendo justicia... hay que dársela!». En sus párrafos podían leerse las siguientes ideas:

A vosotras, mujeres de La Mancha, me dirijo para que vibréis de indignación como vibraba esta mañana el pueblo de Almodóvar del Campo, y porque en esta campaña que emprendemos pidiendo no venganza... ijusticia!... queremos que nos acompañe la opinión de toda la provincia.

[...] Aquel hombre después de cometido el asesinato, fue a entregarse a la justicia, temeroso que la cólera popular, fuera al mismo tiempo juez y verdugo. Cínico

«La ley de Linch en Santander», El Guadalete (Jerez de la Frontera), 10.814, 28-6-1891; las mujeres supuestamente parricidas que se libraron del linchamiento por la pronta intervención de la policía en Málaga y en Sanlúcar de Barrameda (Cádiz) eran tachadas de «desnaturaliza$\mathrm{da}[\mathrm{s}] »$ en «Madre parricida», La Correspondencia de Alicante (Alicante), 4.106, 7-7-1897 y en «Vida de provincias», Heraldo Alavés (Vitoria), 2.174, 2-3-1908; «canalla» y «bandido» eran los calificativos que recibió el supuesto parricida de un pueblo cercano a Valencia que no llegó a ser linchado por los «titánicos esfuerzos» de la fuerza pública para impedir «un asalto a la cárcel hábilmente organizado» en «Pueblo indignado», El Eco de Navarra (Pamplona), 10.473, 15-8-1911.

${ }_{27}$ «El Sr. Solano evita el linchamiento de un asesino», El Pueblo Manchego, 3.193, 07-091921.

${ }_{28}$ «El Sr. Solano evita el linchamiento de un asesino», El Pueblo Manchego, 3.193, 07-091921.

Hispania, 2019, vol. LXXIX, no 263, septiembre-diciembre, págs. 699-725, ISSN: 0018-2141, e-ISSN: 1988-8368 https://doi.org/10.3989/hispania.2019.017 
y despreocupado solo le interesó que no le llevaran por las calles céntricas, sino por las afueras y gracias a la nobleza de este pueblo, no hemos tenido hoy un día de luto y de trágico espanto.

El pueblo con su certero instinto, se daba cuenta que una mujer joven, de excelente familia, rica, bella y virtuosa, se había casado con un hombre que no llegaba ni con mucho, a la mujer que había elegido por compañera.

[...] El pueblo de Almodóvar ciego de cólera, cinco o seis mil hombres y mujeres, llenaban esta mañana las calles y plazas de este pueblo pidiendo que ahorcaran en el acto al asesino.

Había en Almodóvar veinte Guardias civiles que tendrían que cumplir con su deber... ¡no importaba!... se dejaría a los Máuser cincuenta o sesenta hombres, pero pagaría el bandido la pena, merecida, de su culpa... ¡así razonaba la enfurecida muchedumbre, y sobre todo y sobre todos, las mujeres, llorosas e iracundas al mismo tiempo, que animaban a los hombres al cumplimiento de lo que estimaban un acto de justicia!

Hubo que hablar al pueblo, y solo cuando se le dijo que la nobleza de los hijos de esta tierra no podía consentir que nosotros fuéramos tan cobardes como el asesino, matando con abuso de superioridad, y en estado de indefensión, y que era preciso que la justicia hiciera su camino, esta gente campesina que tiene más corazón y más entendimiento de lo que muchos creen, las mujeres más indignadas, se resignaron a que se cumplieran los trámites de la justicia con la condición de que el juicio oral fuera en Almodóvar, y se cumplieran aquí los precedentes que supo enseñarnos, virilmente, el pueblo de Don Benito en Extremadura.

[...] Pediremos que se activen los trámites siempre perezosos de la curia y que llegue pronto la hora en que el castigo justo, tranquilice los ánimos de los que tienen hambre y sed de justicia.

¡Esta mañana el pueblo la pedía rugiendo enfurecido, y yo recordaba aquella frase del insigne escritor Alejandro Dumas: «que la voz del pueblo se parece mucho a la voz de Dios! $)^{29}$

De la primera a la última línea del artículo, el alcalde tiraba de dramatismo y tópicos manidos para justificar el intento de linchamiento, apelando a la desolación de un pueblo herido, a la excitación emocional de las mujeres, la bondad instintiva de los campesinos y su ingenua disposición a dar la vida por elevados ideales de justicia ${ }^{30}$. En verdad, sus palabras derrochaban un fuerte sentido paternalista del poder político, que debía guiar a la población por los caminos de lo correcto, y un mayor esfuerzo por proteger a sus vecinos y atender a sus demandas colectivas. En un escenario de creciente competencia política, es más que probable que las autoridades locales se percatasen del potencial político de algunas reclamaciones de la población, de la necesidad de atender a

${ }^{29}$ « Cuando el pueblo ruge, pidiendo justicia... hay que dársela!», El Pueblo Manchego, 3.197, 12-09-1921.

${ }^{30}$ Los usos políticos de la ignorancia fingida del campesinado han sido estudiados por SCOTT, 2000.

Hispania, 2019, vol. LXXIX, nº 263, septiembre-diciembre, págs. 699-725, ISSN: 0018-2141, e-ISSN: 1988-8368 https://doi.org/10.3989/hispania.2019.017 
algunas de sus peticiones o de aceptar ciertas expresiones de disenso público, del cálculo electoral en la toma de decisiones y de los costes políticos de no transigir. Las protestas y formas de movilización social obligaban a las facciones clientelares a redefinir las relaciones sociales con sus vecinos, desplegar mayores esfuerzos, recursos y marcos de negociación en la gestión del poder local. Un crimen como el ocurrido en Almodóvar brindaba así la oportunidad al poder municipal de abanderar la causa de la indignación popular, recabar apoyos e influencias políticas para conseguir una condena ejemplar y, de conseguirlo, reforzar su autoridad o prestigio en la población ${ }^{31}$.

Estas muestras de comprensión de las elites locales hacia las emociones, comportamientos y demandas populares, no obstante, contrastaban con otras en las que las tentativas de linchamiento denotaban odios o enfrentamientos entre clases sociales, rupturas con la política clientelar o desafíos a la hegemonía política de determinadas familias en la población. La multitud no aparecía representada tan repleta de virtudes en Peñas de San Pedro. En esta población de la provincia de Albacete la chispa estalló cuando el farmacéutico atropelló con su automóvil y mató accidentalmente a una anciana de la población. Era el primer automóvil que llegaba a la población, pero la admiración por los avances de la industria no consiguió eclipsar los recelos que podían suscitar su conductor y propietario. La Guardia Civil tuvo que realizar «verdaderos esfuerzos para impedir su linchamiento»y disolver una «gran manifestación» que pretendía «incendiar la casa en donde se refugió el causante del atropello» ${ }^{32}$. Un año más tarde, en Pozuelo de Calatrava, situado en la provincia de Ciudad Real, otro propietario y hermano de un diputado provincial se libró por poco de ser linchado por sus vecinos cuando era detenido y conducido a la cárcel. Aquí, lejos de alabar el recto sentido de la justicia que poseía el pueblo, los sucesos se representaban en la prensa motivados por el instinto vengativo del pueblo, «el encono y la pasión de la baja política, degenerados en el odio que se transmite

${ }^{31}$ CABO y VEIGA, 2011. CRUZ, 2015. PÉREZ GARZÓN, 2015.

${ }^{32}$ Historial de la Comandancia de la Guardia Civil de Albacete de 1915, Archivo de la Dirección General de la Guardia Civil: 66-67. Los atropellos de los primeros coches y tranvías que aparecieron en pueblos y ciudades como Madrid, Bilbao, Sevilla o Toledo conforman otro de los motivos que suscitaron recurrentemente tentativas de linchamiento contra los conductores imprudentes, en tanto que competían por la ocupación del espacio público con los transeúntes y podían poner en peligro la vida de éstos. Véase, por ejemplo, «Los tranvías que matan. Motín», La Prensa (Santa Cruz de Tenerife), 262, 22-8-1911; «Motín», La Prensa, 1.043, 28-11-1913; «Motín», La Prensa, 1.054, 9-12-1913; «Minuta», El Día de Toledo (Toledo), 1.230, 21-8-1915, «Desgracias», Correo de la mañana (Badajoz), 1.137, 11-7-1917; «Una niña atropellada e intento de linchamiento», La Tierra de Segovia (Segovia), 68, 3-8-1919; y «Atropello, incendio e intento de linchamiento», El Progreso (Santa Cruz de Tenerife), 4.565, 5-61920.

Hispania, 2019, vol. LXXIX, no 263, septiembre-diciembre, págs. 699-725, ISSN: 0018-2141, e-ISSN: 1988-8368 https://doi.org/10.3989/hispania.2019.017 
de generación en generación de padres a hijos, divididos en bandos de distintas familias $)^{33}$.

El detenido había matado de un disparo a un guarda municipal que fue a su casa a recaudar una tasa municipal por los servicios de vigilancia que el ayuntamiento prestaba en los campos de los propietarios. Este propietario, sin embargo, no parecía encontrarse demasiado satisfecho con estos servicios. Quince días antes del suceso, el autor del disparo, su hermano el diputado provincial y «otros parientes y correligionarios» habían viajado a la capital provincial y visitado autoridades y directores de periódicos para denunciar públicamente las «intolerables vejaciones» y los daños que constantemente sufrían sus intereses y campos de cultivo, que consideraban inspiradas «o al menos consentidas» por el «bando político contrario» que en ese momento ocupaba el poder municipal. El disparo alertó a la población y antes de que la Guardia Civil acudiese a la voz de alarma, un «buen número de vecinos» armados de escopetas rodeaban la casa del «matador» para evitar que se fugara y «vengar al desgraciado guarda». El autor del disparo y toda su familia se resistía a la orden de la Guardia Civil de entregarse «por miedo a un linchamiento». Finalmente fue detenido en su domicilio y conducido a la cárcel entre un pasillo de gente que ocupaba las calles de la población. Los iniciales gritos de protesta se convirtieron en «intento de agresión» que los guardias civiles solo pudieron contener «a duras penas» en las puertas de la cárcel ${ }^{34}$.

En suma, todos estos episodios descubren prácticas sociales, significados culturales y usos políticos mucho más complejos que los que se han atribuido a la ignorancia de las clases populares, a una reacción espontánea de ira o a un instinto natural de venganza. Las relaciones sociales en el ámbito local se demostraban capaces de generar vínculos de solidaridad comunitaria o ayuda mutua ante lo que percibían como una amenaza de su equilibrio social, el normal desarrollo de la vida cotidiana o su reputación colectiva. Estos lazos comunitarios daban forma a las más estudiadas revueltas que reaccionaban a los efectos de una economía de mercado en expansión o a las mayores exacciones del Estado, pero también a otras acciones colectivas que respondían a los comportamientos más brutales de sus vecinos, que transgredían las normas consuetudinarias de conducta, la moral pública y privada de la población. Estas tentativas de linchamiento, por tanto, podrían ser la evidencia más violenta de la existencia de una conciencia vecinal o entramado moral en el mundo rural, que definía una particular concepción de justicia y pretendía preservar la integridad de la comunidad frente a lo que entendían como peligros disgregadores, nuevas formas de organizar la convivencia colectiva y administrar justicia.

\footnotetext{
33 «Crimen en el Pozuelo. Un guarda muerto», El Pueblo Manchego, 1.533, 28-2-1916.

34 «Crimen en el Pozuelo. Un guarda muerto», El Pueblo Manchego, 1.533, 28-2-1916.
} 


\section{RESISTENCIA A LA JUSTICIA DEL ESTADO}

Todos los crímenes narrados en las páginas anteriores estaban tipificados en el Código Penal de 1870, ya fuesen calificados como asesinatos, parricidios, homicidios, homicidios imprudentes, lesiones, etcétera. A la mayoría de ellos les correspondían penas muy elevadas por este código, que contemplaba la pena de muerte y la cadena perpetua para los casos más graves y reincidentes $^{35}$. Sin embargo, las multitudes congregadas en estos sucesos preferían otras prácticas de castigo alternativas al sistema oficial de justicia. En los linchamientos, el castigo no estaba dictado por ningún código penal, los presuntos criminales no gozaban de ninguna protección legal y una manera de entender la justicia era aplicada directamente por los propios vecinos de la población. Las garantías que el procedimiento penal del Estado de derecho otorgaba al acusado no tenían ningún efecto en estos linchamientos. La autoridad judicial quedaba desplazada a una posición discutida, controvertida y menos segura. En este sentido, estos episodios de violencia revelan un proceso contencioso entre la sociedad y la representación del Estado por las formas de entender y ejercer el castigo que bien podría alimentar el debate sobre la afirmación del poder estatal y la nacionalización de la política, muy especialmente en el mundo rural ${ }^{36}$.

En estos sucesos es difícil ver a un Estado completamente soberano en su autoridad y reconocimiento público para administrar justicia. En muchos casos analizados el Estado acababa imponiendo su poder, evitando el linchamiento en el último momento debido al empleo de todos los medios a su disposición. En los albores del siglo XX el aparato coercitivo del Estado, a través de las diversas fuerzas del orden público, ya era suficientemente fuerte para imponerse al estallido de una revuelta local en última instan$\mathrm{cia}^{37}$. Aun así, periódicamente seguían conformándose grupos en ámbitos comunitarios que lo desafiaban cuando se sentían ultrajados por un crimen, cuestionaban la injerencia de las autoridades estatales en nombre de una forma de justicia popular y mantenían la expectativa de poder impartir esa justicia a través del linchamiento. Como apunta David Garland, los linchamientos o sus tentativas podrían estar señalando las limitaciones y dificultades a las que todavía estaba expuesto el poder del Estado, la incompleta canalización de determinados conflictos sociales y expresiones de violencia por los procedimientos judiciales e institucionalizados, la renuencia de las autoridades locales a reprimir o denunciar a los participantes en la acción

\footnotetext{
35 SÁNCHEZ GONZÁLEZ, 2017.

${ }^{36}$ MOLINA y CABO, 2010.

37 GONZÁLEZ CALLEJA, 1998; 1999.
} 
de castigo y el poder que ejercían los actores locales en la gestión de su comunidad $^{38}$.

Los representantes del Estado tenían que esforzarse a menudo para controlar el poder de castigar determinados crímenes de sangre que las comunidades se atribuían. En cada ocasión que se conformaba una multitud con afán de castigo se insistía en que los autores de ciertos crímenes brutales debían ser tratados de una forma muy diferente a la contemplada en el derecho penal. Los linchamientos tenían lugar en el ámbito local en el que se había cometido el crimen, expresaban pasiones o sentimientos de indignación que no podía mostrar el idioma oficial de la ley penal, seguían un guión bien conocido por la comunidad, ejercían el castigo de manera inmediata, escenificaban su respaldo popular con la participación masiva de la población, aseguraban la impunidad de la multitud debido a las dificultades o riesgos de identificar a alguien e infligían un terrible grado de sufrimiento en los presuntos criminales que se consideraba más acorde al daño causado por el crimen. La justicia oficial del Estado, en cambio, podía ser considerada por estos linchadores demasiado lejana, demasiado fría, demasiado incierta, demasiado lenta, demasiado respetuosa con los peores criminales o demasiado benévola ${ }^{39}$.

Esto último, debieron pensar las gentes de Villanueva del Fresno, pueblo de la provincia de Badajoz. La libre absolución por un jurado de dos acusados de asesinato y parricidio sobre los que el fiscal pedía pena de muerte cayó como un jarro de agua fría en «gran parte del vecindario». Hacía cinco años desde que se había cometido el crimen pero ni los vecinos lo habían olvidado ni se habían relajado las tensiones. La noticia del inminente regreso de uno de los exculpados acabó por excitar los ánimos del todo. «Grandes grupos» salieron al encuentro del automóvil que lo traía de vuelta a casa y, al llegar éste, «asaltaron el vehículo» y acabaron con su vida «a puñaladas, pedradas y estaca$z O S »{ }^{40}$. En acciones de este tipo se encuentran evidencias de resistencia popular a las nuevas formas estatales de administrar e impartir justicia, plasmadas en la codificación penal liberal, sobre todo cuando sucedían crímenes horrendos que conmocionaban a la sociedad o herían profundamente la sensibilidad de la comunidad. En ocasiones así se podía manifestar cierta incredulidad hacia un sistema judicial que proclamaba la presunción de inocencia y las garantías procesales, decía asegurar la defensa del acusado, eliminaba los castigos corporales, buscaba mayor moderación y proporcionalidad en las penas y convertía

${ }^{38}$ El control de las comunidades locales sobre los procesos penales y sus posibles desarrollos en GARLAND, 2013: 179-185

39 PFEIFER, 2004.

40 «Contra un crimen. El jurado le absuelve, y en el pueblo le linchan», El Debate (Madrid), 2.966, 5-3-1919; «Extremadura», Correo de la Mañana, 1.653, 11-3-1919; y «Lynchamiento», Diario de Córdoba (Córdoba), 21.434, 5-3-1919. 
a la prisión, la pena privativa de libertad o el sistema que obliga a pagar tiempo a los penados, en la principal forma de castigo ${ }^{41}$.

La sociedad de aquel momento exhibía valores retribucionistas ante crímenes atroces, pero atribuirle un sentido vengativo innato o un deseo atemporal de aplicar la ley del talión resulta igualmente problemático. Las formaciones políticas y corrientes de opinión en favor de la abolición de la pena de muerte, la compasión y humanidad por el condenado, habían experimentado significativos avances desde los años del Sexenio Democrático ${ }^{42}$. Las campañas contra ejecuciones de reos, muertes que empezaban a parecer evitables e innecesarias, alcanzaron ecos nacionales e internacionales ${ }^{43}$. La continuada aparición de los linchamientos en la prensa podría ser un indicio del impacto que ocasionaban en los lectores ilustrados las manifestaciones violentas o agresivas que procedían del mundo rural. Lejos de tratarse de un fenómeno desconocido, lo que podría estar cambiando es la sensibilidad social con la que se observaba, o lo que Jan Plamper ha denominado las «normas emocionales» y culturales que impregnaban a la sociedad ${ }^{44}$. No obstante, la conmoción por los crímenes brutales, especialmente en los entornos más cércanos a la víctima, pudo exponer a procesos transitorios, de involución y resistencia popular, la asimilación de las nuevas formas penales y procedimientos judiciales más garantistas. Emociones, pasiones, afectos o sentimientos han estado siempre presentes en los comportamientos humanos, la acción colectiva, la violencia y el castigo. El reciente interés de la historiografía por esta nueva perspectiva de análisis empieza a demostrar la importancia de lo emocional en los procesos de cambio. Además, las emociones han dejado de considerarse una constante antropológica para atribuirles un componente aprendido que se adquiere, experimenta o transforma en un contexto cultural determinado. Esto significa que las emociones pueden y necesitan ser historiadas ${ }^{45}$.

La sensación de inseguridad y violencia o la desconfianza hacia las autoridades y representantes del Estado también podría haber nutrido esta cultura del castigo popular y la persistencia en el tiempo de las tentativas de linchamiento ${ }^{46}$. Las multitudes que participaban en estas acciones pretendían evitar por todos sus medios que el detenido fuese trasladado fuera de la comunidad, querían ser testigos del castigo. A su vez, las autoridades locales trataban de disuadir los ánimos de los linchadores prometiéndoles que el proceso judicial se desarrolla-

\footnotetext{
${ }^{41}$ RAMOS VÁZQUEZ, 2017. GARGALLO VAAMONDE y OLIVER, 2013.

${ }^{42}$ BURILLO, 2011.

${ }^{43}$ OLIVER. 2008. Un estudio de caso sobre el cambio de actitudes políticas y sensibilidades sociales sobre la pena de muerte en BASCUÑÁN AÑOVER, 2016.

${ }^{44}$ PLAMPER, 2014.

45 FREVERT, 2014.

${ }^{46}$ Este debate ha sido mantenido por MILLER, 1998. GARDNER, 1998.
} 
ría en la misma población o en el ámbito judicial más cercano. Lo hemos visto en algunos de los episodios anteriormente narrados y sucedió también en otro pueblo de Badajoz, Zalamea de la Serena, donde seguro que seguía resonando el eco del más célebre episodio de la cercana población de Don Benito ${ }^{47}$. En Zalamea, «grandes grupos» intentaron asaltar la cárcel en varias ocasiones para linchar al presunto asesino de una mujer de la población. La «enérgica intervención» de la guardia civil lo impidió, pero no apaciguó los ánimos de hombres y mujeres que en una «enorme manifestación» pedían «a grandes voces justicia» y gritaban «que el criminal no salga del pueblo bajo ningún pretexto». Con tal propósito, los vecinos establecieron una guardia «que vigila permanentemente la cárcel para impedir, por todos los medios, que el preso salga de Zalamea, donde quieren ver el cumplimiento de la justicia». La llegada del juez instructor volvió a sacar a «numeroso público» a la calle. El temor a que estallasen «gravísimos sucesos» si el juez disponía el traslado del detenido a la cárcel del partido obligó al capitán de la guardia civil a pedir la concentración de más agentes ${ }^{48}$.

Este rechazo a que el acusado se alejase del lugar del crimen, el temor a perder capacidad de presión e influencia en las decisiones del juez o a que el presunto criminal se librase del castigo, muestran la existencia de una desconfianza hacia la administración de justicia que se acrecentaba conforme se distanciaba del ámbito local. La justicia fue una de las administraciones más desprestigiadas de la España liberal en estas décadas. Los jueces municipales solo necesitaban saber leer y escribir para ocupar el cargo y sus actuaciones solían favorecer a las élites locales y sus clientelas. Los jueces de instrucción carecían de una formación judicial regulada y sus nombramientos, promociones y traslados estaban estrechamente vinculados a redes clientelares e intereses políticos. La justicia era utilizada por los caciques para deshacerse de adversarios políticos, suspender ayuntamientos o procesar a concejales de la oposición. Muchos veían en ella una institución clasista, corrupta y ajena a las costumbres de la población ${ }^{49}$. La copla por la que fueron procesados varios jornaleros de una población de Toledo expresa cabalmente este estado de opinión: «Entra el ladrón en la audiencia/se pone delante del juez/si le enseña cinco duros/sale como hombre de bien $»^{50}$. Esta imagen social era también compartida por parte de las altas instancias judiciales. En 1896, el Fiscal del Tribunal Supremo lo manifestaba del siguiente modo:

\footnotetext{
47 VILABELLA, 1983.

48 «Zalamea de la Serena», Correo de la mañana, 1.759, 3-7-1919.

49 FIESTAS LOZA, 1997.

50 Sentencia 239, Archivo de la Audiencia Provincial de Toledo, Libro de Sentencias, sec-
} ción 2 . ${ }^{\mathrm{a}}, 1898$.

Hispania, 2019, vol. LXXIX, nº 263, septiembre-diciembre, págs. 699-725, ISSN: 0018-2141, e-ISSN: 1988-8368 https://doi.org/10.3989/hispania.2019.017 
En los núcleos rurales, sobre todo, el mal alcanza proporciones gigantescas. Rudos, indoctos, políticos menudos de profesión como recurso para escalar los puestos, sin noción de la justicia ni conocimientos de sus deberes, los Jueces municipales son un escollo para la tranquilidad y sosiego de los pueblos, y motivo más que suficiente para hacer aborrecible entre las gentes sensatas la función de la justicia. Debiendo su nombramiento a la política, sólo a la política sirven. El adversario, en lugar de un juez, halla siempre un enemigo que disfruta las prerrogativas del cargo [...] Con sólo la instrucción elemental, a veces muy rudimentaria, y regulada su conducta por miras estrechas de parcialidad y bandería, el Juez municipal es la negación de la justicia y el imperio del capricho y la tiranía ${ }^{51}$.

La instauración del juicio por jurados en 1888 no consiguió mejorar la autonomía de la justicia ni su impopularidad. La medida tenía vocación democratizadora, pretendía abrir las puertas de la administración de justicia a la ciudadanía e involucrarla en la impartición de justicia con relación a los delitos más graves contra las personas y la propiedad. Sin embargo, la actividad del jurado no se libró de sufrir fuertes influencias políticas. El caciquismo logró infiltrarse en los juicios en los que sus intereses estaban comprometidos, mediando en la elección de los miembros del jurado, recusando a jueces y jurados díscolos, manejando los tiempos procesales, sobornando a testigos, condicionando los veredictos y comprando el perdón. Los escándalos judiciales y veredictos de inculpabilidad fueron aireados continuamente en la prensa, que contribuyó a crear un clima de cuestionamiento social y descrédito de la justicia ${ }^{52}$. Episodios como el célebre suceso del Crimen de Cuenca ilustran la persistencia de las carencias y falta de credibilidad, respeto y reconocimiento de la justicia oficial del Estado. En este suceso, fueron condenados dos hombres a dieciocho años de cárcel por el asesinato de un pastor de su población en 1910. Años más tarde se descubrió que la presunta víctima mortal había huido voluntariamente de la población y se encontraba afincado en otra donde preparaba su boda. El escándalo obligó a destapar las presiones políticas que había sufrido la administración de justicia para encontrar a los culpables del falso asesinato y las torturas de la Guardia Civil que sufrieron los procesados para autoinculparse ${ }^{53}$.

En este contexto de falta de confianza en la justicia del Estado también encontraron su lugar los enfrentamientos públicos con jueces y fuerzas del orden, resistencias abiertas a detenciones y algunos asaltos a cárceles locales para liberar a vecinos $^{54}$. La aparición de nuevas formas de organización política y movilización

${ }^{51}$ Memoria elevada al Gobierno de Su Majestad por el Fiscal del Tribunal Supremo, Archivo del Ministerio de Justicia, 1896: 15.

52 ALEJANDRE, 1981. EGEA BRUNO, 2015.

${ }^{53}$ LÓPEZ VILLAVERDE, 2010.

${ }^{54}$ Más de una decena de estos episodios de liberación de presos en BASCUÑÁN AÑOVER, 2008. Otros muchos casos en LUCEA AYALA, 2005. REDONDO CARDEÑOSO, 2011.

Hispania, 2019, vol. LXXIX, no 263, septiembre-diciembre, págs. 699-725, ISSN: 0018-2141, e-ISSN: 1988-8368 https://doi.org/10.3989/hispania.2019.017 
de intereses colectivos no consiguió desactivar ni canalizar todas las expresiones de violencia colectiva. La percepción generalizada de corrupción, parcialidad y abuso de poder en el ejercicio de las funciones públicas, de este modo, pudo sostener en el tiempo estallidos de acción colectiva, brutales y de castigo para reparar crímenes atroces. Las tentativas de linchamiento podían actuar, así, como prácticas dramáticas que representaban el descrédito de los centros de poder. En este sentido, estas expresiones de violencia colectiva, además de incitar a explorar el tejido de relaciones sociales y valores culturales vigentes en la sociedad, hacen necesario el análisis de las estructuras políticas, las características y límites del poder del Estado. El desarrollo histórico de los linchamientos, por tanto, lejos de transitar un camino civilizatorio certero y directo hacia su paulatina extinción ha podido estar expuesto a involuciones en escenarios de debilidad, ineficacia y desconfianza en el poder político ${ }^{55}$.

\section{Conclusiones}

Los episodios narrados han permitido ofrecer algunas respuestas a las preguntas iniciales de este trabajo. Los crímenes de sangre, los que más carga dramática demostraban para conmocionar a la sociedad, provocaron multitudinarias y repetidas tentativas de linchamiento en las poblaciones donde se había cometido el suceso. El paso que media entre la indignación contenida y el estallido de la acción colectiva, no obstante, podría venir dado por un conjunto de relaciones locales y estructuras políticas que permiten la violencia. La acción pública de castigo exhibía valores culturales en la medida en que los miembros de la comunidad manifestaban vínculos de solidaridad, formas propias de entender la justicia y el castigo y una preocupación compartida por mantener normas de conducta, una moral pública y privada, que preservasen ciertos modos de convivencia e integridad de la población. Exhibiciones brutales de voluntad y poder popular que, además, ofrecían oportunidades políticas a las élites locales para situarse al frente de las demandas, apuntalar su prestigio y reconocimiento social. La resistencia, expresada en los linchamientos, a dejar determinados crímenes en manos de la administración de justicia también revela la existencia de otras prácticas de castigo en la sociedad muy diferentes a los procedimientos liberales, que pudieron persistir o alimentarse en un contexto de desconfianza y descrédito de los representantes públicos e instituciones del Estado.

${ }_{55}$ El debate sobre el proceso civilizatorio en ELIAS, 2000. Otros caminos del desarrollo en los que la violencia extralegal puede tener reservados diferentes espacios, prácticas y actores en SPIERENBURG, 1984. TILLY, 1992. NORTH, WALLIS y WEINGAST, 2009. 
Otros muchos nuevos interrogantes surgen de esta primera investigación. Ahondar en esta línea de investigación requiere desentrañar una mayor tipología de causas que pudieron desencadenar linchamientos. ¿Aparecieron otras causas políticas, sociales, religiosas y xenófobas, o cobraron mayor relevancia en contextos de intensificación de la disputa política, debilidad o desconfianza en el poder político? Las actitudes de las elites locales también merecen mayor atención. ¿La comprensión y tolerancia hacia los castigos multitudinarios por crímenes horrendos se tornó en algún momento en rechazo y condena? En este mismo sentido, cabría preguntarse si la existencia de serias tensiones políticas y sociales influyeron en la reconsideración de las élites locales hacia los linchamientos, como un mayor intento por controlar la violencia colectiva. ¿Y los cambios culturales, nuevas consideraciones sobre la violencia y el castigo en la sociedad, han desempeñado algún papel en este proceso? Por último, sería preciso ampliar horizontes espaciales, temporales y comparativos para indagar en la relación entre los procesos de afirmación y debilidad de las estructuras del Estado y el número y la intensidad de estos linchamientos. En definitiva, los próximos trabajos deberían ahondar en la compleja relación entre las estructuras de poder, las normas culturales, las relaciones sociales y la acción colectiva. De este modo, se aspira a alcanzar una mayor comprensión de los traumáticos retornos a los que esta forma de justicia popular han quedado expuestos.

\section{BibliogRAFÍA}

Acha, Gloria, Huellas de fuego: crónica de un linchamiento, Cochabamba, Bolivia, Acción Andina, 2003.

Alejandre, Juan Antonio, La justicia popular en España. Análisis de una experiencia histórica: los tribunales de jurados, Madrid, Universidad Complutense, 1981.

Allen, James (ed.), Without sanctuary: lynching photographs in America, Santa Fe, Twin Palms, 2000.

Anitua, Gabriel Ignacio y Yamamoto, María Verónica (dirs.), Pena de muerte. Fundamentos teóricos para su abolición, Buenos Aires, Didot, 2011.

Baroja, Pío, El árbol de la ciencia, Madrid, Cátedra, 1996 [1911].

Bascuñán Añover, Óscar, Protesta y supervivencia. Movilización y desorden en una sociedad rural: Castilla-La Mancha, 1875-1923, Valencia, Fundación Instituto Historia Social, 2008.

Bascuñán Añover, Óscar, «La pena de muerte en la Restauración: una historia del cambio social», Historia y Política, 35 (Madrid, 2016): 203-230.

Baumeister, Martin, Campesinos sin tierra. Supervivencia y resistencia en Extremadura, 1880-1923, Madrid, Ministerio de Agricultura, 1996.

Brundage, William Fitzhugh, Lynching in the New South: Georgia and Virginia, 1880-1930, Urbana, University of Illinois Press, 1993. 
Brundage, William Fitzhugh (ed.), Under sentence of death: lynching in the South, Chapel Hill, University of North Carolina Press, 1997.

Burillo, Fernando, La cuestión penitenciaria. Del Sexenio a la Restauración (18681913), Zaragoza, Prensas Universitarias de Zaragoza, 2011.

Burke, Peter, La cultura popular en la Europa moderna, Madrid, Alianza, 1991.

Cabo, Miguel y Vázquez Varela, José Manuel, «Las otras guerras de nuestros antepasados: la violencia intercomunitaria en la Galicia rural contemporánea», Hispania, 251 (Madrid, 2015): 781-804.

Cabo, Miguel y Veiga, Xosé, «La politización del campesinado en la época de la Restauración. Una perspectiva europea», en Teresa Ortega y Francisco Cobo (eds.), La España rural, siglos XIX y XX. Aspectos políticos, sociales y culturales, Granada, Comares, 2011: 21-58.

Cardesín, José María, «Motín y magnicidio en la Guerra de la Independencia: la voz de «arrastrar» como modelo de violencia colectiva», Historia Social, 62 (Valencia, 2008): 27-47.

Carrigan, William D., The making of a lynching culture: violence and vigilantism in central Texas, 1836-1916, Urbana, University of Illinois Press, 2006.

Carrigan, William D. y Webb, Clive, Forgotten dead: mob violence against Mexicans in the United States, 1848-1928, Oxford, Oxford University Press, 2013.

Chauvaud, Frédéric y Mayaud, Jean-Luc (dirs.), Les violences rurales au quotidien, París, La Boutique de 1'histoire, 2005.

Corbin, Alain, Le village des «cannibales», París, Flammarion, 1995.

Cruz, Rafael, Protestar en España, 1900-2013, Madrid, Alianza, 2015.

Cruz Artacho, Salvador, «Política y mundo rural en la España del siglo XX: Socialización política, participación electoral y conquista de la democracia», en Encarna Nicolás Marín y Carmen González Martínez (coords.), Mundos de ayer. Investigaciones históricas contemporáneas del IX Congreso de la Asociación de Historia Contemporánea, Murcia, Servicio de publicaciones de la Universidad de Murcia, 2009: 249-278.

Dale, Elizabeth, «The role of popular justice in U.S. history», en Paul Knepper y Anja Johansen (eds.), The Oxford handbook of the history of crime and criminal justice, Oxford, Oxford University Press, 2016: 539-554.

Darnton, Robert, La gran matanza de gatos y otros episodios en la historia de la cultura francesa, Madrid, Fondo de Cultura Económica, 2006.

Egea Bruno, Pedro María, «Mata al Rey y vete a Murcia. La corrupción de la justicia en la España de la Restauración», Studia Histórica. Historia Contemporánea, 33 (Salamanca, 2015): 159-192.

Elias, Norbert, The civilizing process, Oxford, Basil Blackwell, 2000 [1939].

Evans, Richard, Rituals of retributions: capital punishment in Germany, 1600-1987, Oxford, Oxford University Press, 1996.

Fiestas Loza, Alicia, «Justicia y amigos políticos en el siglo XIX», en Javier Alvarado Planas (coord.), Poder, economía, clientelismo, Madrid, Marcial Pons, 1997: 233-255.

Foucault, Michel, Vigilar y castigar. Nacimiento de la prisión, Madrid, Siglo XXI, 1979.

Frevert, Ute, «The modern history of emotions: a research center in Berlin», Cuadernos de Historia Contemporánea, 36 (Madrid, 2014): 31-55. 
Gardner, John, «Crime: in proportion and in perspective», en Andrew Ashworth y Martin Wasik (eds.), Fundamentals of sentencing theory, Oxford, Oxford University Press, 1998: 31-52.

Gargallo Vaamonde, Luis y Oliver, Pedro, «Desarrollo y colapso del penitenciarismo liberal», en Pedro Oliver (coord.), El siglo de los castigos. Prisión y formas carcelarias en la España del siglo XX, Barcelona, Anthropos, 2013: 15-62.

Garland, David, «Penal excess and surplus meaning: public torture lynchings in Twentieth-Century America», Law \& Society Review, 39 (Nueva York, 2005): 793-834.

Garland, David, Una institución particular. La pena de muerte en Estados Unidos en la era de la abolición, Buenos Aires, Didot, 2013.

Gil Andrés, Carlos, Echarse a la calle. Amotinados, huelguistas y revolucionarios (La Rioja, 1890-1936), Zaragoza, Prensas Universitarias de Zaragoza, 2000.

Gómez Bravo, Gutmaro, Crimen y castigo. Cárceles, justicia y violencia en la España del siglo XIX, Madrid, Los Libros de la Catarata, 2005.

González Calleja, Eduardo, La razón de la fuerza. Orden público, subversión y violencia en la España de la Restauración (1875-1917), Madrid, CSIC, 1998.

González Calleja, Eduardo, El máuser y el sufragio. Orden público, subversión y violencia política en la crisis de la Restauración (1917-1931), Madrid, CSIC, 1999.

Herrera, Antonio, Markoff, John y Villa, Inmaculada, «La democratización del mundo rural en España en los albores del siglo XX. Una historia poco conocida», Ayer, 89 (Madrid, 2013): 21-42.

López Villaverde, Ángel Luis, El crimen de Cuenca en treinta artículos: antología periodística del error judicial, Cuenca, Universidad de Castilla-La Mancha, 2010.

Lucea Ayala, Víctor, Rebeldes y amotinados. Protesta popular y resistencia campesina en Zaragoza (1890-1905), Zaragoza, Institución «Fernando el Católico» y Prensas Universitarias de Zaragoza, 2005.

Martins, José de Souza, Linchamentos. A justiça popular no Brasil, São Paulo, Editora Contexto, 2015.

Miguez, Antonio y Cabo, Miguel, «Pisando la dudosa luz del día: el proceso de democratización en la Galicia rural de la Restauración», Ayer, 89 (Madrid, 2013): 43-65.

Miller, William, «Clint Eastwood and equity: popular culture's theory of revenge», en Austin Sarat y Thomas Kearns (eds.), Law in the domains of culture, Ann Arbor, University of Michigan Press, 1998.

Molina, Fernando y Cabo, Miguel, «An inconvenient Nation: Nation building and national identity in Spain, 1808-1936. The historiographical debate», en Maarten Van Ginderachter y Marnix Beyen (eds.), Nationhood from below: Europe in the long nineteenth century, Basingstoke, Palgrave Macmillan, 2010: 47-72.

North, Douglass C., Wallis, John Joseph, y Weingast, Barry R., Violence and social orders. A conceptual framework for interpreting recorded human history, Cambridge, Cambridge University Press, 2009.

Ogletree, Charles J. y Sarat, Austin (eds.), From lynch mobs to the killing state: race and the death penalty in America, New York, New York University Press, 2006.

Oliver, Pedro, La pena de muerte en España, Madrid, Síntesis, 2008.

Pan-Montojo, Juan y Pedersen, Frederik (eds.), Communities in European history. Representatios, jurisdictions, conflicts, Pisa, Pisa University Press, 2007.

Hispania, 2019, vol. LXXIX, no 263, septiembre-diciembre, págs. 699-725, ISSN: 0018-2141, e-ISSN: 1988-8368

https://doi.org/10.3989/hispania.2019.017 
Pérez Garzón, Juan Sisinio, Contra el poder: conflictos y movimientos sociales en la historia de España, Granada, Comares, 2015.

Pfeifer, Michael, Rough justice: lynching and American society, 1874-1947, Urbana, University of Illinois Press, 2004.

Plamper, Jan, «Historia de las emociones: caminos y retos», Cuadernos de Historia Contemporánea, 36 (Madrid, 2014): 17-29.

Ramos Vázquez, Isabel, «Historia del régimen penitenciario en España (1834-1936)», en Javier Alvarado Planas y Miguel Martorell Linares (coords.), Historia del delito y del castigo en la Edad Contemporánea, Madrid, Dykinson, 2017: 121-151.

Ranzato, Gabriele, Il linciaggio di Carretta (Roma, 1944). Violenza politica e ordinaria violenza, Milano, Il Saggiatore, 1997.

Redondo Cardeñoso, Jesús Ángel, Protesta y violencia de los campesinos castellano-leoneses: La Tierra de Campos (1900-1923), Palencia, Diputación de Palencia/Diputación de Valladolid, 2011.

Rudé, George, El rostro de la multitud. Estudios sobre revolución, ideología y protesta popular, Valencia, Biblioteca Historia Social, 2000.

Sánchez González, Dolores del Mar, «Delitos y penas en los códigos penales españoles», en Javier Alvarado Planas y Miguel Martorell Linares (coords.), Historia del delito y del castigo en la Edad Contemporánea, Madrid, Dykinson, 2017: 97-119.

Scott, James C., Los dominados y el arte de la resistencia. Discursos ocultos, México, Ediciones Era, 2000.

Spierenburg, Pieter, The spectacle of suffering. Executions and the evolution of repression: from a preindustrial metropolis to the European experience, Cambridge, CUP, 1984.

Thompson, Edward, P., Costumbres en común, Barcelona, Crítica, 2000 [1. ed. en castellano, 1995).

Tilly, Charles, Coerción, capital y los estados europeos (990-1990), Madrid, Alianza, 1992.

Tilly, Charles, Violencia colectiva, Barcelona, Hacer, 2007.

Tomás y Valiente, Francisco, Manual de historia del derecho español, Madrid, Tecnos, 2002 [1979].

Townson, Nigel, «Racismo, Red Scare y sindicalismo en los Estados Unidos», en Fernando del Rey y Manuel Álvarez Tardío (dirs.), Politicas del odio. Violencia y crisis en las democracias de entreguerras, Madrid, Tecnos, 2017: 335-386.

Trinidad, Pedro, La defensa de la sociedad. Cárcel y delincuencia en España (siglos XVIII-XX), Madrid, Alianza, 1991.

Vandiver, Margaret, Lethal punishment: lynchings and legal executions in the South, New Brunswick, NJ, Rutgers University Press, 2006.

Vaquinhas, Irene María, Violência, justiça e sociedade rural. Os campos de Coimbra, Montemor-o-Velho e Penacova de 1858 a 1918, Oporto, Edições Afrontamento, 1996.

Vilabella, José Manuel, El crimen de Don Benito, Madrid, Albia, 1983.

Recibido: 28/06/2018

Aceptado: 08/05/2019

Hispania, 2019, vol. LXXIX, nº 263, septiembre-diciembre, págs. 699-725, ISSN: 0018-2141, e-ISSN: 1988-8368 https://doi.org/10.3989/hispania.2019.017 